\title{
PEMBERDAYAN SERTA PENINGKATAN PEMBANGUNAN MANUSIA MENUJU MASYARAKAT YANG SEHAT, CERDAS DAN SEJAHTERA BERSAMA BKKBN
}

Fidyah Jayatri' ${ }^{1}$, Dwi Yanuarindah Putri ${ }^{2}$

${ }^{1}$ STKIP PGRI Lumajang

${ }^{2}$ STKIP PGRI Lumajang

fidyah.jaya3@gmail.com¹,dwi.y.putri@gmail.com

Submited : 30 July 2020 | Acepted : 09 Agustus 2020 | Published : Desember 2020

\begin{abstract}
Abstrak
Mitra program ini adalah BKKBN Desa Tukum Kabupaten Lumajang. Di desa ini, banyak ditemukan pengendalian jumlah anak yang tidak stabil sehingga pihak BKKBN Desa Tukum harus berperan ekstra demi menyadarkan masyarakat terkait program peningkatan pembangunan manusia yang meliputi pola hidup sehat, pengetahuan, serta standar hidup layak. Permasalahan selama ini disebabkan karena pihak BKKBN kesulitan mengumpulkan warga untuk memberikan sosialisasi berkala terkait programnya. Tim lapangan BKKBN yang jumlahnya hanya dua orang, selama ini harus berjuang door to door menemui warganya. Kenyataannya pemahaman yang kurang dari beberapa bagian warga Desa Tukum disebabkan rasa acuh atas himbauan BKKBN yang membuat mereka tidak sepenuhnya mengerti apa yang harus dilakukan jikalau jumlah anggota keluarga bertambah namun tidak mampu mewujudkan hidup yang layak bagi keluarga mereka. Tidak meratanya informasi karena jangkauan tim lapangan BKKBN yang terbatas menyebabkan permasalahan angka kelahiran tidak pernah selesai. Kondisi ini membuat tim lapangan BKKBN resah karena pertambahan angka kelahiran tiap tahun yang selalu meningkat, meskipun selama ini mereka berjuang keras menyadarkan masyarakat tentang pentingnya membuat program berencana bagi kehidupan. Melalui kegiatan pengabdian kepada masyarakat bekerja sama dengan mahasiswa KKN angkatan 2015, sosialisasi program BKKBN sangat terbantu. Penyuluhan berkala yang ditutup dengan diskusi bersama warga membuat BKKBN dapat diterima oleh warga desa.
\end{abstract}

Kata kunci: progam BKKBN, peningkatan pembangunan manusia. 


\section{PENDAHULUAN}

Dewasa ini kita indeks pembangunan manusia menjelaskan sebagai upaya penduduk mampu mengakses hasil pembangunan untuk memperoleh pendapatan, kesehatan, pendidikan. Indeks pembangunan manusia sendiri sesuai data Badan Pusat Statistik memiliki tiga dimensi dasar yaitu pola hidup sehat, pengetahuan, serta standar hidup layak (BPS, 2020). Kegiatan pengabdian ini dilakukan dalam beberapa tahapan guna menjembatani komunikasi BKKBN dengan warga Tukum untuk mewujudkan msayarakat yang sehat, cerdas, serta sejahtera. Konsep dari kegiatan pengabdian ini didasarkan atas temuan mahasiswa KKN di Desa Tukum yang menunjukan usia muda di desa tersebut telah memiliki banyak anak.

Saat ini pihak BKKBN Desa Tukum kesulitan mengumpulkan warga guna memberikan sosialisasi berkala terkait programnya. Tim lapangan BKKBN yang jumlahnya hanya dua orang, selama ini harus berjuang door to door menemui warganya. Ternyata kurangnya pemahaman beberapa warga Desa Tukum disebabkan rasa acuh atas himbauan BKKBN yang membuat mereka tidak sepenuhnya mengerti apa yang harus dilakukan jikalau jumlah anggota keluarga bertambah namun tidak mampu mewujudkan hidup yang layak bagi keluarga mereka. Tidak meratanya informasi karena jangkauan tim lapangan BKKBN yang terbatas menyebabkan permasalahan angka kelahiran tidak pernah selesai. Kondisi ini membuat tim lapangan
BKKBN resah karena pertambahan angka kelahiran tiap tahun yang selalu meningkat, meskipun selama ini mereka berjuang keras menyadarkan masyarakat tentang pentingnya membuat program berencana bagi kehidupan.

Adapun sasaran dari kegiatan pengabdian kepada masyarakat yaitu mengacu pada perwujudan pembangunan masyarakat usia produktif dengan harapan pemerataan tingkat pembangunan manusia di Desa Tukum serta terjadi peningkatan pengetahuan yang bermuara pada peningkatan kualitas SDM. Ketercapaian dua hal tersebut diharapkan mampu meningkatkan produktivitas usia kerja, sehingga pada akhirnya mampu meningkatkan mutu hidup yang layak. Menurut Raharti, dkk (51:2020) pertumbuhan ekonomi mempengaruhi indeks pembangunan manusia, begitu juga sebaliknya. Hasil penelitian ini menunjukkan bahwa pemerataan pertumbuhan ekonomi harus dicapai sebuah wilayah agar pembangunan manusia dapat meningkat juga. Kenyataannya, tidak semua wilayah di Desa Tukum memiliki pembangunan manusia yang sama, yang mana Desa Tukum bagian barat berbatasan langsung dengan Kota Lumajang sudah memiliki pertumbuhan ekonomi yang baik. Hal ini dilihat dari tersedianya fasilitas umum yang sangat memadai seperti masjid besar, sekolah dasar sampai sekolah menengah, homestay dan komplek perumahan. Sesuai hasil penelitian yang dilakukan Lonni,et. al. (2018) bahwa pertumbuhan ekonomi dan sumber daya manusia saling mempengaruhi sehingga dalam jangka panjang merupakan faktor penting untuk kemajuan bangsa. Hal 
ini benar nyatanya karena pada hasil temuan lapangan, tim PKM menemukan banyak perbedaan yang terjadi antar wilayah desa Tukum.

Perbedaan yang terlihat adalah ketertinggalan wilayah desa yang tidak sama dengan wilayah barat. Wilayah utara dan timur masih bernuansa desa dan saat ini pun pertumbuhan ekonomi tidak terlihat sama dengan wilayah barat yang sudah maju. Temuan tim PKM dengan mahasiswa KKN angkatan 2015 itulah yang mendasari kami untuk bekerja sama dengan BKKBN wilayah Desa Tukum.

\section{TINJAUAN PUSTAKA}

\section{Ekonomi Pembangunan}

Dalam ilmu ekonomi, secara khusus ekonomi pembangunan merupakan salah satu cabang ilmu yang multidisiplin yang mampu mengakomodasi tiga tujuan utama pembangunan. Tujuan utama dari cabang ilmu ini yang pertama adalah pembangunan yang berpusat pada manusia yang memiliki empat elemen penting yaitu kesehatan, pendidikan, kebebasan bergerak, dan bebas dari rasa takut. Kedua yaitu pembangunan yang ramah lingkungan yang mana konsep dari sebuah pembangunan ini bermaksud memasukkan isu kondisi lingkungan yang tidak hanya sebagai sebuah model alternatif namun juga bisa sebagai model ekonomi. Terakhir, pembangunan sebagai sebuah poses multidimensi yang akan melibatkan perubahan dalam stuktur sosial dengan diikuti oleh percepatan pertumbuhan ekonomi, terjadi penurunan kondisi ketidaksetaraan, dan pembenahan kondisi miskin di masyarakat.

Secara khusus, pembangunan harus mampu mewakili seluruh perubahan dalam sistem sosial, yang disesuaikan dengan heterogenitas kebutuhan dasar dan pendapat yang mungkin berkembang dari seorang individu dan komunitas sosial. Pembangunan ekonomi sendiri merupakan sebuah proses kenaikan pendapatan total dan pendapatan perkapita secara kualitatif yang bukan hanya menghitung pertambahan produksi, tetapi juga terdapat perubahan-perubahan dalam struktur produksi dan alokasi input pada berbagai sektor perekonomian seperti dalam lembaga, pengetahuan, dan teknik dengan memperhatikan terjadinya kesejahteraan penduduk. Kesejahteraan ini dapat dicapai melalui peningkatan kualitas pembangunan manusia dengan cara meningkatkan kesehatan, pendidikan dan juga kondisi ekonominya.

\section{Pembangunan Manusia}

Untuk mengukur tercapainya pembangunan ekonomi suatu negara maka setiap negara harus mengukur indeks pembangunan manusia (IPM) secara berkala. Kondisi yang heterogen di Indonesia menjadikan indeks pembangunan manusia tidak merata. Yang penting untuk diperhatikan adalah peranan indeks pembangunan manusia (IPM) sebagai sebuah indikator untuk mengukur kualitas perkembangan manusia. Indeks Pembangunan Manusia (IPM) sendiri memiliki tiga aspek penting, yaitu pendidikan, kesehatan, dan ekonomi (daya beli). Selain itu, perkembangan 
manusia juga dipengaruhi oleh beberapa faktor lain, meliputi ketersediaan peluang kerja, pertumbuhan ekonomi, infrastruktur, dan kebijakan pemerintah daerah.

Perkembangan manusia yang baik akan membuat usia rata-rata masyarakat meningkat dan lebih lanjut terjadi peningkatan pengetahuan dengan bermuara pada perbaikan kualitas sumber daya manusia. Selanjutnya peningkatan tersebut akan berlanjut pada peningkatan produktivitas yang akhirnya akan meningkatkan kualitas hidup yang layak. Seperti dalam paparan Todaro dan Smith (2015), kesejahteraan manusia haruslah berarti baik, dalam arti menjadi dasar untuk sehat, terpelihara dengan baik, pakaian yang pantas, melek huruf, dan umur panjang. Lebih lanjut hasil penelitian Yektiningsih (2018) mengungkapkan bahwa konsep pembangunan manusia memenuhi dimensi yang sangat luas dengan banyak pilihan, hanya mungkin tercapai jika penduduk tersebut memiliki peluang angka harapan hidup yang tinggi atau umur panjang dan sehat, memiliki pengetahuan dan ketrampilan atau keahlian serta mempunyai peluang atau kesempatan merealisasikan pengetahuan tersebut dalam kajian produktif.

\section{Kemiskinan}

Bedasarkan paparan di depan erat hubungannya antara konteks pembangunan manusia terhadap kemiskinan. Kemiskinan menurut Chamber dalam Suradi (2007) didefinisikan sebagai “... suatu keadaan melarat dan ketidakberuntungan, suatu keadaan minus (deprivation)", bila dimasukkan dalam konteks tertentu, hal itu berkaitan dengan "minimnya pendapatan dan harta, kelemahan fisik, isolasi, kerapuhan dan ketidakberdayaan". Lebih lanjut Amartya Sen dalam Suradi (2007) mengungkapkan bahwa terdapat sebuah inti dari kemiskinan. Kondisi kelaparan yang melanda masyarakat merupakan sebuah perspektif keadaan miskin, demikian juga dengan ketidakmampuan dalam kehinaan sosial dan ketidakmampuan dalam memberi pendidikan anak-anak serta merawat kesehatannya.

Dari paparan tersebut penulis menyimpulkan bahwa ketercapaian pembangunan manusia dapat terjadi jika harapan hidup manusia tinggi dengan umur panjang yang sehat diimbangi dengan pendidikan dan kehidupan yang layak. Kesehatan sendi memiliki kesinambungan dengan masa reproduksi manusia seperti yang sudah dijelaskan dalam program BKKBN. Usia orang tua yang terlalu muda berpengaruh pada kondisi kesehatan di masa mendatang. Berikut juga akan berdampak pada kondisi ekonomi yang mana usia muda masih belum mampu mencukupi kebutuhan ekonominya sendiri sehingga akan berdampak pada ketergantungan ekonomi orang tuanya.

Sejalan dengan pemikiran inilah, maka hasil penelitian Mirza (2012) menunjukkan bahwa semakin tinggi populasi penduduk miskin akan menekan tingkat pembangunan manusia, sebab penduduk miskin memiliki daya beli yang rendah. Populasi pendudukan yang terus bertambah tanpa diimbangi dengan kualitas tingkat pendidikan, kesehatan, dan ekonomi (daya beli) akan mengarahkan manusia kepada 
kemiskinan. Adanya peningkatan ketiga indikator tersebut diharapkan akan terjadi peningkatan kualitas hidup manusia. Hal inilah yang mendorong BKKBN mencapai visi menjadi lembaga yang handal dan dipercaya dalam mewujudkan penduduk tumbuh seimbang dan keluarga berkualitas (BKKBN:2020).

\section{METODE PENGABDIAN MASYARAKAT}

\section{Waktu Pengabdian}

Kegiatan pengabdian kepada masyarakat ini berlangsung dalam beberapa tahapan sehingga membutuhkan waktu beberapa minggu, yaitu

Tanggal : 08 Agustus 2018 s.d 27

Agustus 2018

Pukul : 09.00 s.d selesai

Tempat: a. Posyandu Perumahan Tukum

b. Kantor Desa Tukum, Kecamatan Tekung Kabupaten Lumajang

\section{Prosedur Pelaksanaan PKM}

Secara garis besar, prosedur pelaksanaan kegiatan pengabdian kepada masyarakat ini dilakukan melalui serangkaian kegiatan berikut:

a. Identifikasi masalah di lapangan bekerja sama dengan mahasiswa KKN,

b. Pembentukan tim PKM,

c. Kerjasama dengan BKKBN wilayah desa Tukum, Kecamatan Tekung,

d. Pembuatan proposal PKM,

e. Koordinasi antara tim PKM dengan khalayak sasaran,

f. Pelaksanaan kegiatan program kependudukan serta pemantauan lebih lanjut tentang kondisi masyarakat setelah dilaksanakannya program ini,

g. Pembuatan laporan PKM

\section{Sasaran}

Sasarankegiatanpengabdiankepadamasyarakat ini adalah terealisasinya program PKM STKIP PGRI Lumajang Program Studi Pendidikan Ekonomi bersinergi dengan mahasiswa KKN angkatan 2015 dan BKKBN Kabupaten Lumajang sebagai bentuk pendampingan bagi pengembangan manusia di wilayah Desa Tukum kabupaten Lumajang secara integral dan terpadu.

Melalui asas kerjasama atau kemitraan antara STKIP PGRI Lumajang dengan BKKBN Kabupaten Lumajang dan masyarakat Desa Tukum Kecamatan Tekung maka kegiatan PKM ini dilaksanakan sebagai bentuk implementasi dari salah satu cara dalam peningkatan pembangunan manusia yang didorong oleh LPPM STKIP PGRI Lumajang yaitu meningkatkan kemampuan mahasiswa melalui kegiatan KKN dalam memecahkan permasalahan masyarakat dan pengembangan manusia di wilayah Desa Tukum melalui kegiatan penyuluhan dan membantu pelaksanaan program-program BKKBN.

\section{HASIL DAN PEMBAHASAN}

\section{Tahap Kegiatan Pengabdian Kepada}

Masyarakat

Kegiatan pengabdian kepada masyarakat oleh dosen Program Studi Pendidikan Ekonomi bekerja sama dengan mahasiswa KKN angkatan 2015 mendapat sambutan yang luar biasa khususnya dari tim lapangan BKKBN yang sangat terbantu atas kegiatan ini. Pada 
HUMANISM Vol.1 No. 3 Desember 2020

umumnya usia mahasiswa berkisar antara 17 tahun hingga 24 tahun. Menurut Hurlock (2006) pada usia tersebut individu berada pada masa remaja akhir dan dewasa awal. Artinya mahasiswa KKN yang bertugas saat itu berada pada periode perkembangan sebagai remaja akhir. Dengan begitu mahasiswa yang memperoleh pemahaman konkret pentingnya membuat program berencana untuk kehidupan di masa akan datang.

Dengan demikian maka tugas perkembangan mahasiswa antara lain memperluas hubungan dan komunikasi interpersonal, memperoleh peranan sosial, menerima keadaan tubuhnya, memperoleh kebebasan emosional dari orang tua dan orang dewasa lainnya, mencapai kemandirian, mempersiapkan pekerjaan untuk masa depan, mempersiapkan diri membentuk keluarga dan membentuk sistem nilai moral dan juga prinsip hidup. Dalam kesempatan ini, mahasiswa mendapatkan banyak sekali gambaran konkret untuk persiapan kehidupan nyata setelah lulus dari bangku kuliah. Program pengabdian kepada masyarakat yang bekerja sama dengan mahasiswa KKN serta pihak BKKBN memberikan manfaat yang besar baik bagi tim pengabdian, mahasiswa, maupun petugas BKKBN. Mahasiswa kreatif melakukan pendekatan dengan masyarakat membuat tim BKKBN sangat terbantu untuk memasukkan informasi terkait programnya.

Berikut ini bentuk kegiatan yang sudah dilaksanakan tim pengabdian beserta mahasiswa KKN angkatan tahun 2015 bekerja sama dengan tim BKKBN Kabupaten

Tabel 1. Tahap Kegiatan Pengabdian Kepada Masyarakat

\begin{tabular}{|c|c|c|c|}
\hline NO & PROGRAM & KEGIATAN & PELAKSANAAN \\
\hline 1. & $\begin{array}{l}\text { Pojok } \\
\text { Kependudukan }\end{array}$ & $\begin{array}{ll}\text { a. } & \text { Pembuatan pojok } \\
& \text { kependudukan } \\
\text { b. } & \text { Penyusunan dan } \\
& \text { pengenalan Program KB }\end{array}$ & $\begin{array}{l}\text { Waktu : 08 Agustus } 2018 \\
\text { Tempat : Kantor Desa Tukum } \\
\text { Sasaran : Seluruh staf desa dan } \\
\text { Masyarakat Desa Tukum }\end{array}$ \\
\hline 2. & $\begin{array}{l}\text { Bina Keluarga } \\
\text { Lansia }\end{array}$ & $\begin{array}{l}\text { a. Mengukur tinggi dan } \\
\text { berat badan } \\
\text { b. Mengecek gula darah, } \\
\text { kolestrol, dan obesitas }\end{array}$ & $\begin{array}{l}\text { Waktu : } 11 \text { Agustus } 2018 \\
\text { Tempat : Di posyandu Perumahan } \\
\text { Tukum } \\
\text { Sasaran : Ibu Lansia usia } \pm 50 \\
\text { Tahun }\end{array}$ \\
\hline 3. & $\begin{array}{l}\text { Bina Keluarga } \\
\text { Balita }\end{array}$ & $\begin{array}{l}\text { a. Mengukur berat dan } \\
\text { tinggi badan } \\
\text { b. Imunisasi } \\
\text { c. Pemberian Vitamin }\end{array}$ & $\begin{array}{l}\text { Waktu : } 16 \text { Agustus } 2018 \\
\text { Tempat : Posyandu Manggis Desa } \\
\text { Tukum } \\
\text { Sasaran : Balita usia } 0-5 \text { tahun }\end{array}$ \\
\hline 4. & $\begin{array}{l}\text { Bina Keluarga } \\
\text { Remaja }\end{array}$ & $\begin{array}{l}\text { a. Sosialisasi Kesehatan } \\
\text { Reproduksi Remaja }\end{array}$ & $\begin{array}{l}\text { Waktu : } 27 \text { Agustus } 2018 \\
\text { Tempat : Kantor Kepala Desa } \\
\text { Tukum } \\
\text { Sasaran : Remaja usia 17-21 Tahun }\end{array}$ \\
\hline 5 & $\begin{array}{l}\text { Penyuluhan } \\
\text { warga desa } \\
\text { Tukum bersama } \\
\text { tim lapangan } \\
\text { BKKBN }\end{array}$ & $\begin{array}{l}\text { a. Sosialisasi dan diskusi } \\
\text { bersama warga yang } \\
\text { menghadirkan }\end{array}$ & $\begin{array}{l}\text { Waktu : } 27 \text { Agustus } 2018 \\
\text { Tempat : Kantor Desa Tukum } \\
\text { Sasaran : Seluruh staf desa dan } \\
\text { masyarakat Desa Tukum usia } \\
\text { produktif }\end{array}$ \\
\hline
\end{tabular}




\section{Hasil Kegiatan Pengabdian Kepada} Masyarakat

Berdasarkan tahapan di depan maka hasil yang ingin dicapai dalam kegiatan pengabdian ini meliputi:

a. Terbentuknya jembatan komunikasi antara warga Desa Tukum dan petugas BKKBN agar di kemudian hari komunikasi yang baik dapat terjalin.

b. Terbentuknya pemahaman masyarakat terkait program BKKBN guna meningkatkan wawasan pentingnya pembangunan manusia dengan mengikuti program program tim BKKBN.

a. Terbukanya akses tim BKKBN dengan warga desa Tukum khususnya daerah tertinggal agar mau menerima kehadiran tim lapangan BKKBN di kemudian hari dengan tangan terbuka.

Berikut dokumentasi kegiatan yang sudah dilaksanakan selama kegiatan berlangsung.

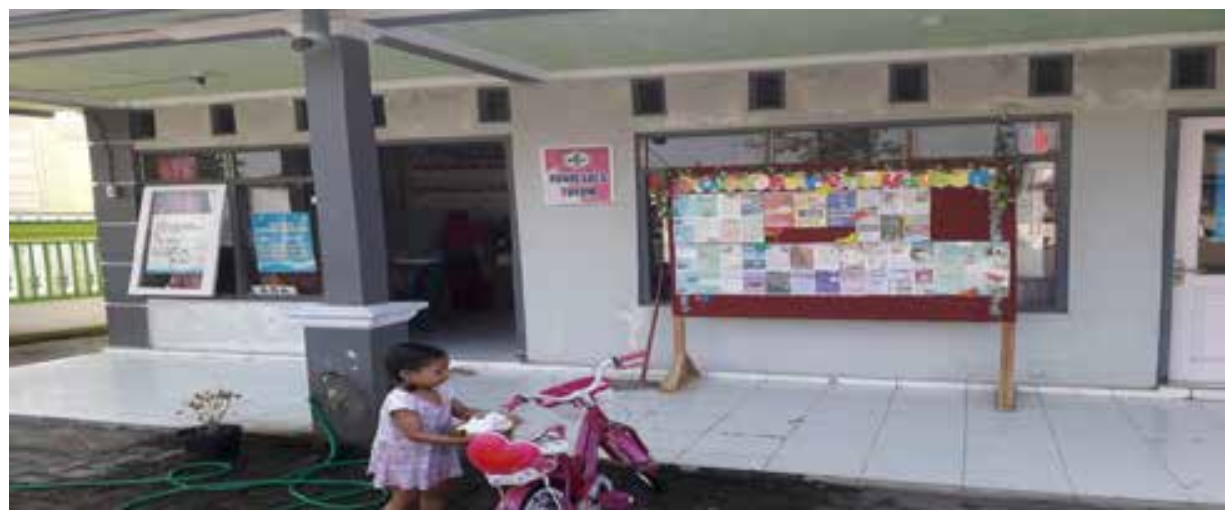

Gambar 1. Pojok Kependudukan yang Diletakkan di Depan Pintu Masuk Balai Desa

Sumber : dokumentasi penulis

Kegiatan pojok kependudukan digunakan untuk memberi informasi terkait masalah kependudukan yang sering terjadi dilingkungan masyarakat disertai informasi tentang upaya mengatasi beragam masalah tersebut. Informasi ini ditempel pada papan mading dan diganti secara berkala sesuai kebaruannya. Informasi ini berada di balai Desa Tukum. Masyarakat yang tidak melek huruf dapat bertanya ke pihak desa tentang info yang sudah diletakkan di papan informasi tersebut. Investasi informasi dalam bidang pendidikan dan kesehatan ini tentunya akan sangat berarti bagi penduduk miskin dibandingkan penduduk tidak miskin, karena aset utama penduduk miskin hanyalah tenaga kasar mereka. Tersedianya fasilitas pendidikan dan kesehatan akan sangat membantu untuk meningkatkan produktifitas, dan pada saat meningkatkan pendapatan. Dengan demikian dapat disetujui pembangunan manusia belum optimal dilakukan karena hanya terfokus pada persetujuan kemiskinan. 

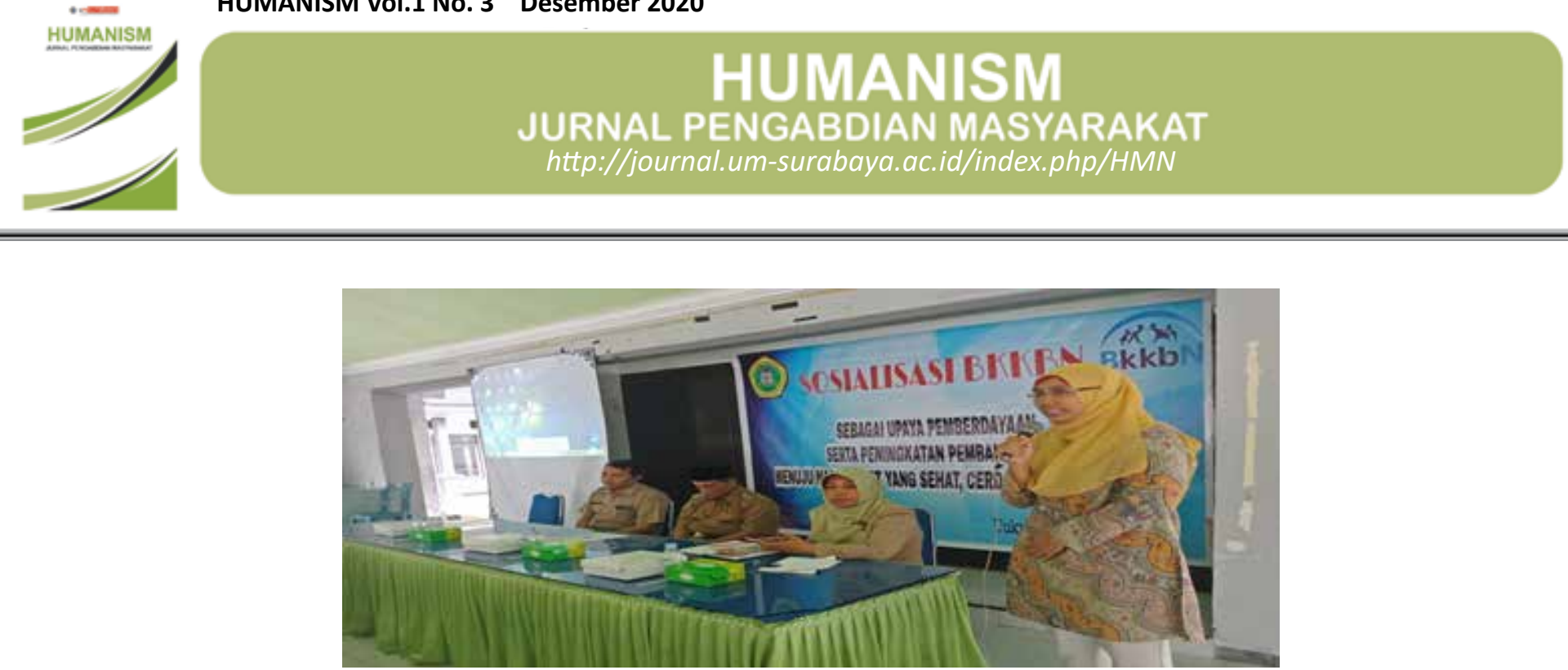

Sumber : dokumentasi penulis

Gambar 2 Giat diskusi Warga bersama Tim PKM yang bermitra BKKBN

Diskusi terbuka bermitra pihak BKKBN merupakan bagian akhir dari kegiatan pengabdian ini. Kegiatan ini mencari respon dan masukan dari warga terkait program BKKBN. Progam ini dilaksanakan di Balai Desa Tukum melalui pendekatan dengan perangkat desa, kader posyandu, serta warga berusia produktif. Respon para kader dan warga yang sangat baik terlihat dari antusias mereka mengikuti progam ini.

Para warga dan kader yang hadir sangat antusias mencatat dan bersiap menanyakan hal yang terasa krusial serta perlu mendapat penanganan. Antusias warga ini menjadi tolok ukur keberhasilan program pengabdian karena mampu diterima dan direspon positif yang mana selama ini tidak pernah ada kegiatan semacam ini di lingkungan Desa Tukum. Harapan ke depan yaitu tetap ada kelanjutan dari kegiatan ini yang difasilitasi pihak desa agar masyarakat secara bersama-sama bersedia memperoleh segala informasi yang berkaitan dengan perbaikan kondisi saat ini. Sesuai dengan hasil penelitian Yektiningsih (2018) bahwa pembangunan manusia harus memenuhi dimensi yang sangat luas dengan banyak pilihan, hanya mungkin tercapai jika penduduk tersebut memiliki peluang angka harapan hidup yang tinggi atau umur panjang dan sehat, memilikipengetahuan dan ketrampilan atau keahlian serta mempunyai peluang atau kesempatan merealisasikan pengetahuan tersebut dalam kajian produktif.

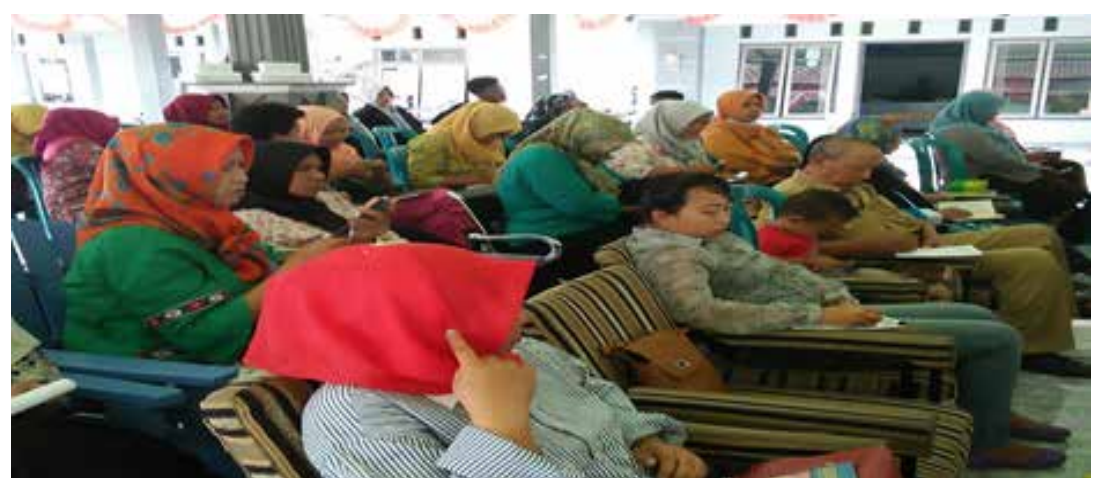

Sumber : dokumentasi penulis

Gambar 3. Antusias warga dalam proses tanya jawab 


\section{KESIMPULAN}

Kesimpulan dari pengabdian yang kami lakukan dapat diketahui bahwa masyarakat sangat memerlukan kegiatan seperti ini. Masyarakat secara langsung diperkenalkan metode yang berbeda dari sebelumnya. Melalui program yang dibuat oleh tim pengabdian bersama mahasiswa $\mathrm{KKN}$ secara tersirat mampu menyampaikan informasi secara berkala yang sangat penting untuk diberikan kepada masyarakat. Melalui program itulah masyarakat menyadari bahwa program BKKBN memang seharusnya bisa diterima dengan tangan terbuka. Tidak ada lagi rasa malas atau takut ketika tim lapangan BKKBN mengundang masyarakat untuk mengikuti informasi terkini seputar program kesehatan dan kesejahteraan masyarakat. Kegiatan ini menjadi media komunikasi antara masyarakat dengan pihak BKKBN, serta meyakinkan masyarakat pentingnya mengikuti arahan pihak BKKBN untuk mencapai pembangunan manusia yang hakiki dalam mewujudkan masyarakat yang sejahtera.

\section{UCAPAN TERIMA KASIH}

Rasa terima kasih kami ditujukan kepada berbagai pihak yang membantu tercapainya kegiatan pengabdian ini. Terima kasih kami sampaikan kepada :

a. LPPM STKIP PGRI Lumajang yang telah memberikan pendanaan terkait kegiatan ini

b. Kepala desa Tukum, Kecamatan Tekung-Kabupaten Lumajang yang membuka ruang bagi tim PKM untuk berbagi ilmu c. Warga desa Tukum, Kecamatan Tekung-Kabupaten Lumajang yang sangat antusias dalam menyambut kedatangan Tim PKM

d. Mahasiswa KKN angkatan 2015 Prodi Pendidikan Ekonomi dan Prodi Pendidikan Matematika STKIP PGRI Lumajang

\section{DAFTAR PUSTKA}

BKKBN. 2020. Visi dan Misi BKKBN. http:// jatim.bkkbn.go.id/530-2/

BPS. 2020. Peningkatan Kualitas SDM Tercermin dalam IPM.

Hurlock, E. B. 2006. Psikologi Perkembangan Suatu Pendekatan Sepanjang Rentang

Kehidupan. Edisi kelima. Alih bahasa Istiwidayanti dan Soedjarwo. Jakarta:

Erlangga.

Lonni, Kasnawi, T., \& Uppun, P. 2018. Pengaruh Kualitas Sumber Daya Manusia

terhadap pertumbuhan ekonomi di kabupaten Mamasa.

http://pasca.unhas.ac.id/jurnal/files/4013e 72 702847521673251f61042c080. pdf.

Miza, Deni S. 2012. Pengauh Kemiskinan, Petumbuhan Ekonomi, dan Belanja Modal

Tehadap Indeks Pembangunan Manusia di Jawa Tengah Tahun 2006-2009.

Economics Development Analysis Journal. Vol 1, No 2 (1-15)

Raharti, Rini dkk. 2020. Analisis Pertumbuhan Ekonomi dan Indeks Pembangunan Manusia di Daerah Istimewa Yogyakarta. Jurnal Perspektif Ekonomi Darussalam. 2020. Vol. 6, No. 1 (36-53) 
Todaro, Michael P. dan Smith, Stephen C.

2015. "Pembangunan Ekonomi". Edisi

Kesebelas. Jakarta: Erlangga.

Yektiningsih, Endang. 2018. Analisis

Indeks Pembangunan Manusia (IPM) Kabupaten

Pacitan Tahun 2018. Journal Universitas

Wijaya Kusuma Surabaya. Vol.18, No.

$2(32-50)$ 